\title{
Teaching NeuroImages: Sulcal artery syndrome
}

\section{A hemicord infarct presenting with incomplete Brown-Sequard syndrome}

Jie Ming Nigel Fong, MBBS, Gee Jin Ng, MBBS, MRCP, MMEd, and Nigel C.K. Tan, MBBS, FRCP, FAMS, MHPEd

Neurology ${ }^{\circledR}$ 2018;90:e1177-e1178. doi:10.1212/WNL.0000000000005218

\section{Correspondence}

Dr. Fong

nigelfong@gmail.com

Figure $1 \mathrm{MRI}$ shows C5 hemicord T2 hyperintensity
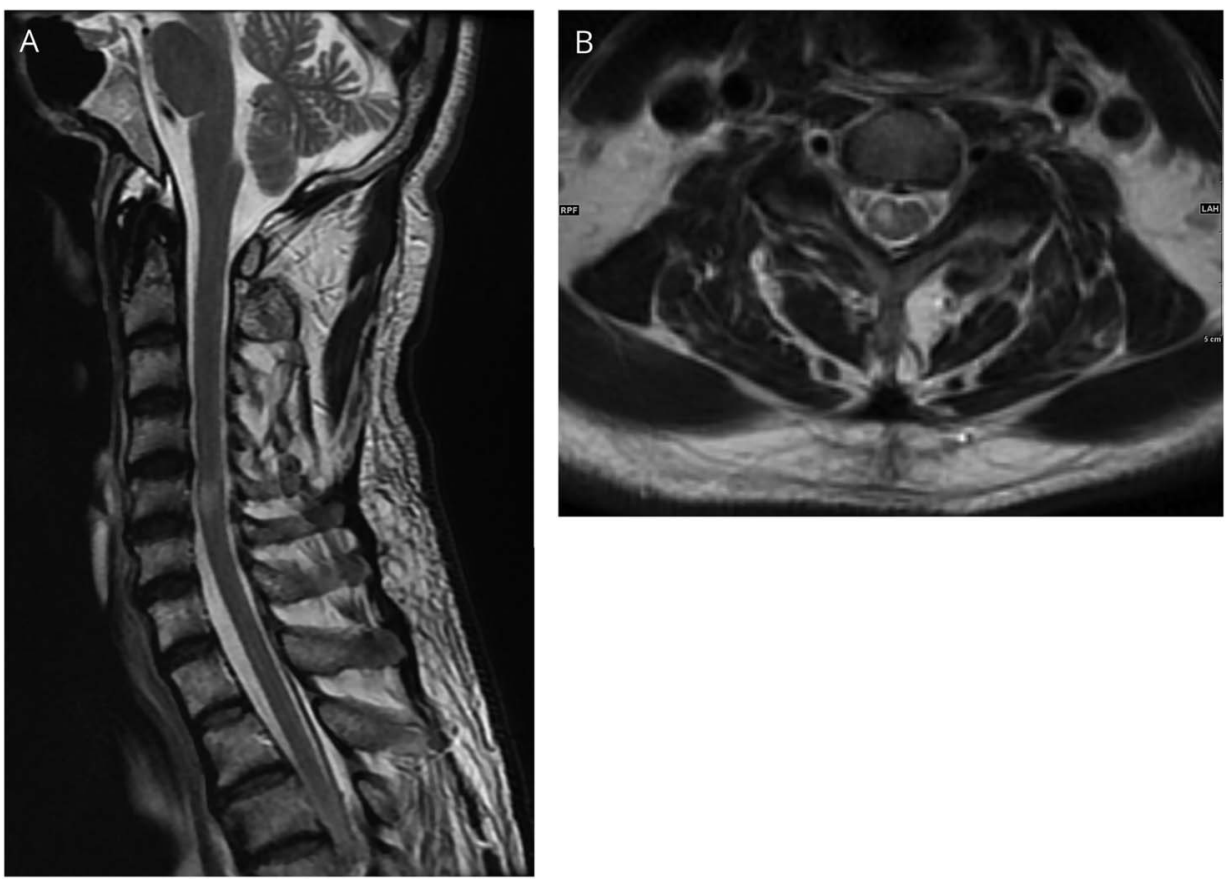

T2-weighted MRI sequence (day 3), sagittal (A) and axial (B) sections.

A 59-year-old man with a history of smoking presented with acute right hemiparesis, pain, and temperature loss on the left below T4 and impaired left-sided abdominal reflexes. Proprioception and vibration were normal. MRI (day 3) showed a short segment of T2 hyperintensity at the right half of C5 spinal cord (figure 1); diffusion-weighted MRI (day 5) demonstrated restricted diffusion (figure 2), confirming hemicord infarct. Sulcal artery occlusion presents with incomplete Brown-Sequard syndrome and is uncommon, unlike the more common anterior spinal artery syndrome. ${ }^{1}$ It preferentially involves the cervical cord. ${ }^{2}$ With physiotherapy, aspirin, and statins, this patient recovered well.

\section{Author contributions}

J.M.N. Fong: writing of manuscript. G.J. Ng: writing of manuscript. N.C.K. Tan: study concept and design, critical revision of manuscript.

\section{Acknowledgment}

The authors thank Dr. Yu Wai-Yung (National Neuroscience Institute) for providing the MRI.

\section{MORE ONLINE}

$\rightarrow$ Teaching slides:

links.lww.com/WNL/A298

From the Division of Medicine (J.M.N.F.), Singapore Health Services; and Department of Neurology (G.J.N. and N.C.K.T.), National Neuroscience Institute, Singapore.

Go to Neurology.org/N for full disclosures. Funding information and disclosures deemed relevant by the authors, if any, are provided at the end of the article. 

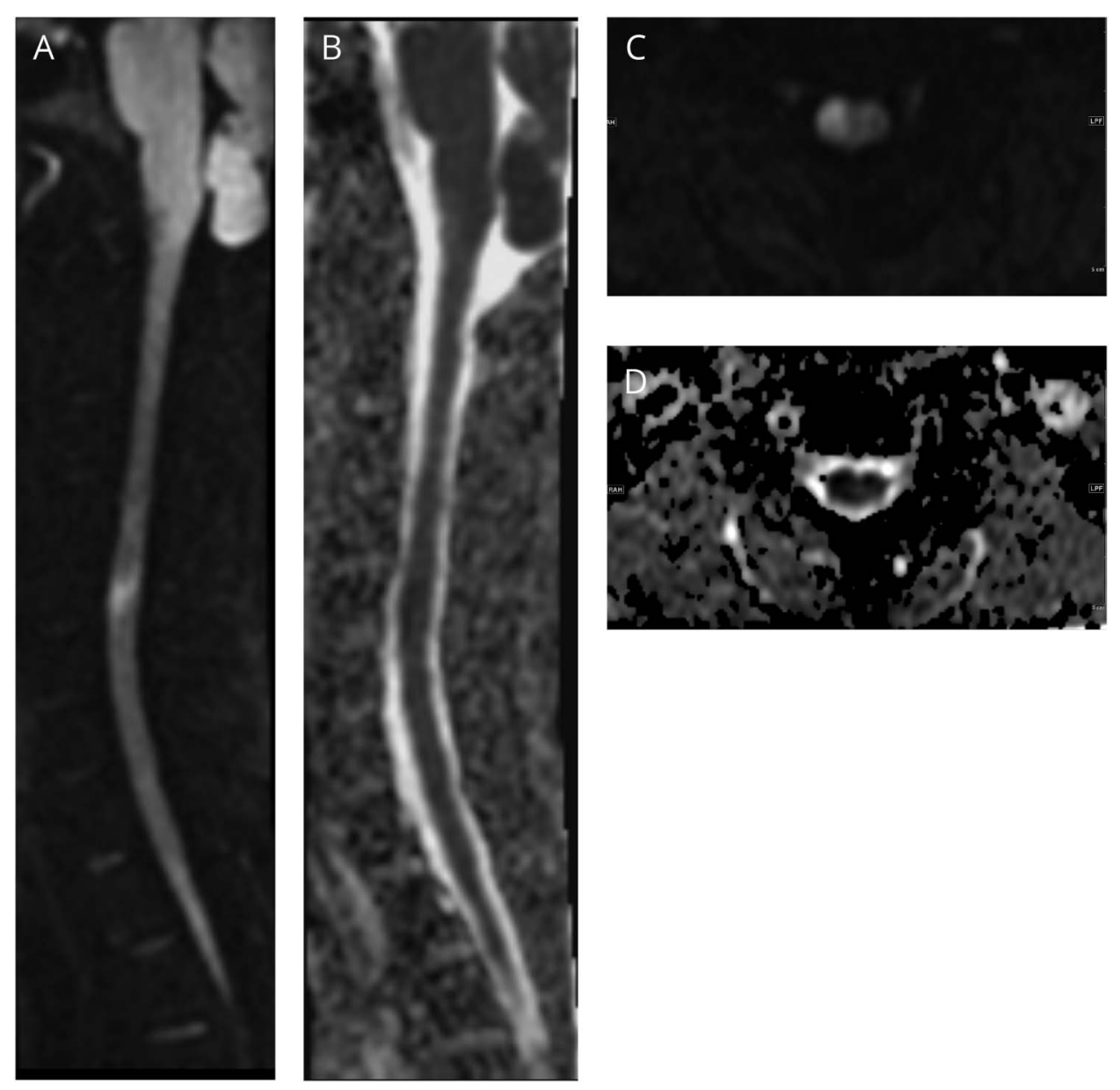

Diffusion-weighted MRI sequence (day 5), diffusion-weighted sagittal (A) and axial (C) and apparent diffusion coefficient sagittal (B) and axial (D) sections.

\section{Study funding}

No targeted funding reported.

\section{Disclosure}

J.M.N. Fong and G.J. Ng report no disclosures relevant to the manuscript. N.C.K. Tan owns stock in Novartis, Pfizer, and Johnson \& Johnson. Go to Neurology.org/N for full disclosures.

\section{References}

1. Rabinstein AA. Vascular myelopathies. Continuum 2015;21:67-83.

2. Weidauer S, Nichtweiß M, Hattingen E, Berkefeld J. Spinal cord ischemia: aetiology, clinical syndromes and imaging features. Neuroradiology 2015;57:241-257. 


\section{Neurology}

Teaching NeuroImages: Sulcal artery syndrome: A hemicord infarct presenting with incomplete Brown-Sequard syndrome

Jie Ming Nigel Fong, Gee Jin Ng and Nigel C.K. Tan

Neurology 2018;90; $11177-\mathrm{e} 1178$

DOI 10.1212/WNL.0000000000005218

This information is current as of March 26, 2018

\section{Updated Information \&} Services

References

Subspecialty Collections

Permissions \& Licensing

Reprints including high resolution figures, can be found at: http://n.neurology.org/content/90/13/e1177.full

This article cites 2 articles, 0 of which you can access for free at: http://n.neurology.org/content/90/13/e1177.full\#ref-list-1

This article, along with others on similar topics, appears in the following collection(s):

DWI

http://n.neurology.org/cgi/collection/dwi

MRI

http://n.neurology.org/cgi/collection/mri

Spinal cord infarction

http://n.neurology.org/cgi/collection/spinal_cord_infarction

Information about reproducing this article in parts (figures,tables) or in its entirety can be found online at:

http://www.neurology.org/about/about_the_journal\#permissions

Information about ordering reprints can be found online:

http://n.neurology.org/subscribers/advertise

Neurology ${ }^{\circledR}$ is the official journal of the American Academy of Neurology. Published continuously since 1951, it is now a weekly with 48 issues per year. Copyright () 2018 American Academy of Neurology. All rights reserved. Print ISSN: 0028-3878. Online ISSN: 1526-632X.

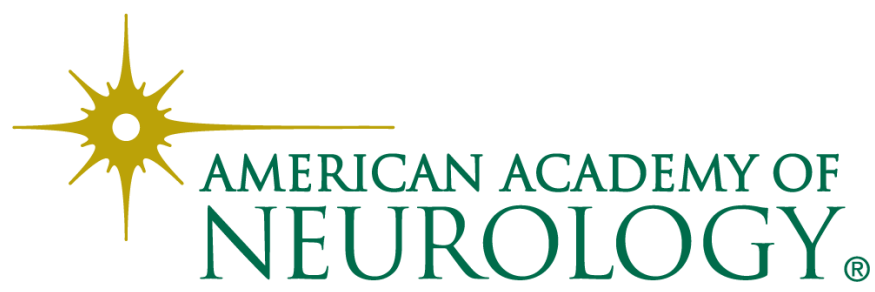

